\title{
UPAYA MENINGKATKAN HASIL BELAJAR SISWA KELAS VA MIN MERAUKE PADA TEMA ORGAN GERAK HEWAN DAN MANUSIA SUB TEMA ORGAN GERAK HEWAN MELALUI METODE COURSE REVIEW HORAY TAHUN PELAJARAN 2018/2019 SEMESTER GANJIL
}

\author{
HUSMAIDAH \\ MIN Merauke Papua
}

\begin{abstract}
ABSTRAK
Penelitian tindakan kelas ini bertujuan untuk mengetahui: 1). Untuk mendeskripsikan penerapan metode Course Review Horay pada mata pelajaran IPA sub tema organ gerak hewan pada siswa kelas Va MIN Merauke. 2). Untuk mengetahui prestasi belajar siswa setelah diterapkannya metode Course Review Horay pada pelajaran IPA sub tema organ gerak hewan pada siswa kelas Va MIN Merauke. Metode penelitian yang digunakan dalam penelitian ini adalah penelitian tindakan yaitu Penelitian Tindakan Kelas (PTK). subjek adalah peserta didik kelas VA MIN Merauke berjumlah 22 orang. objek dari penelitian ini adalah pelaksanaan pembelajaran IPA dengan metode Course Review Horay pada kelas VA MIN Merauke. Waktu penelitian Juli 2018. Alat Pengumpul Data adalah lembar observasi, wawancara, tes dan dokumentasi. Hasil penelitian diperoleh Peningkatan hasil belajar siswa berdasarkan hasil angket minat belajar dari siklus I ke siklus II masuk dalam kriteria tinggi. Peningkatan hasil belajar dari siklus I ke siklus II berhasil mencapai kriteria ketuntasan minimal. Peningkatan hasil minat dan hasil belajar telah memenuhi kriteria keberhasilan.
\end{abstract}

Kata Kunci: Hewan, gerak, organ, Course Review Horay,

\section{ABSTRACT}

This class action research aims to find out: 1). To describe the application of the Course Review Horay method in science subjects sub-themes of animal organs in Va MIN Merauke class students. 2). To find out student achievement after applying the Course Review Horay method in the science lessons sub-theme of animal organ movements in Va MIN Merauke class students. The research method used in this research is action research namely Classroom Action Research (CAR). The subjects were 22 students of VA MIN Merauke class. The object of this research is the implementation of science learning with the Course Review Horay method in the VA MIN Merauke class. Research time July 2018. Data collection tools are observation sheets, interviews, tests and documentation. The results obtained by the increase in student learning outcomes based on the results of the questionnaire interest in learning from cycle I to cycle II are included in the high criteria. Improved learning outcomes from cycle I to cycle II succeeded in reaching the minimum completeness criteria. Increased results of interest and learning outcomes have met the criteria for success.

Keywords: Animals, motion, organs, Course Review Horay

\section{PENDAHULUAN}

Pendidikan bagi kehidupan manusia di bumi termasuk bangsa Indonesia merupakan kebutuhan mutlak yang harus dipenuhi dan dikembangkan sejalan dengan tuntutan pembangunan secara tahap demi tahap. Tanpa pendidikan sangat mustahil manusia dapat hidup berkembang sejalan dengan citacita untuk maju, sejahtera, dan bahagia menurut pandangan hidup mereka. Pendidikan adalah usaha sadar untuk menyiapkan peserta didik agar dapat berperan aktif dan positif dalam hidupnya sekarang dan yang akan datang. Sasaran pendidikan adalah manusia. Pendidikan bermagsud membantu peserta didik untuk menumbuh kembangkan potensi-potensi kemanusiaan (Tirtarahardja, 2005). Hakekat manusia sebagai ciptaan Tuhan adalah makhluk yang mempunyai harkat dan martabat paling tinggi diantara makhluk Tuhan Lainnya dimuka bumi. Ia dianugrahi berbagai kemampuan dasar yang disebut fitrah tyang bisa tumbuh dan berkembang tahap demi tahap kearah kesempurnaan jasmaniah dan rohaniah serta bisa diarahkan melalui proses pendidikan (Arifin $\mathrm{M}$ dan
Rasyad, A. 1997) Pendidikan nasional telah disebutkan bahwa:

Pendidikan nasional adalah pendidikan yang berdasarkan Pancasila dan Undang-Undang Dasar Negara Republik Indonesia Tahun 1945 yang berakar pada nilai-nilai agama, kebudayaan nasional Indonesia dan tanggap terhadap tuntutan perubahan zaman (Departemen Agama RI, 2007)

Kualitas pendidikan di Indonesia dianggap oleh banyak kalangan masih rendah. Hal ini bisa dilihat dari beberapa indikator. Pertama, lulusan dari sekolah atau perguruan tinggi yang belum siap memasuki dunia kerja karena minimnya kompetensi yang dimiliki. Kedua, peringkat Human Development Index (HDI) Indonesia yang masih rendah. Ketiga, laporan International Educational Achievement (IEA) bahwa kemempuan membaca siswa SD di Indonesia barada di urutan 38 dari 39 negara yang di survei. Keempat, mutu academic antyar bangsa melalui Programme for International Student Assasment (PISA) menunjukkan bahwa dari 41 negara yang di survey untuk bidang IPA, Indonesia memempati peringkat ke-38, sementara untuk bidang metematika 
dan kemampuan membaca menenpati peringkat ke-39 (Kunandar, 2010).

Guna mencapai tujuan pendidikan nasional itu tidak segampang apa yang kita harapkan, disamping membutuhkan biaya yang cukup banyak juga dalam proses pelaksanaan pendidikannya harus ditangani manusia yang betulbetul mampu dan dapat menguasai masalah pendidikan serta harus mempunyai dedikasi yang tinggi agar nantinya dapat memproduk kader-kader pembangunan yang tangguh dan yang berkualitas tinggi sesuai dengan harapan dan tujuan pendidikan nasional.

Belajar adalah suatu proses yang kompleks yang terjadi pada diri setiap orang sepanjang hidupnya. Proses belajar terjadi kerena adanya interaksi antara seseorang dengan lingkungannya. Apabila proses balajar itu diselenggarakan secara formal di sekolah-sekolah, tidak lain dimagsudkan untuk mengarahkan perubahan pada diri siswa secara terencana, baik dalam aspek pengetahuan, ketrampilan maupun sikap. Interaksi yang terjadi selama proses belajar tersebut dipengaruhi oleh lingkungannya, yang antara lain terdiri atas murid, guru, petugas perpustakaan, kepala sekolah, bahan atau materi pelajaran dan berbagai sumber belajar dan fasilitas penunjang pembelajaran.

Ilmu pengetahuan alam (IPA) merupakan salah satu disiplin ilmu yang berhubungan dengan cara mencari tau tentang alam secara sistimatis, sehingga IPA bukan hanya penguasaan, kumpulan pengetahuan fakta-fakta, konsep-konsep, atau prinsip prinsip saja. Tapi pada kenyatanya sampai saat ini dalam pembelajaran IPA siswa hanya bisa menghafal konsep yang dipelajarinya, tetapi siswa kurang mampu untuk menghubungkan antara apa yang mereka pelajari dengan bagaimana pengetahuan tersebut akan dimanfaatkan. Untuk itu diperlukan suatu upaya dalam rangka meningkatkan mutu pendidikan dan pengajaran salah satunya adalah dengan memilih strategi atau cara dalam menyampaikan materi pelajaran agar diperoleh peningkatan prestasi belajar siswa khususnya pelajaran IPA. Misalnya dengan mcmbimbing siswa untuk bersama-sama terlibat aktif dalam proses pembelajaran dan mampu membantu siswa berkembang sesuai dengan taraf intelektualnya akan lebih menguatkan pemahaman siswa terhadap konsepkonsep yang diajarkan.

Sehubungan dengan hal itu maka dibutuhkan suatu kegiatan yang dilakukan oleh guru dengan upaya meningkatkan prestasi belajar siswa, misalnya dengan membimbing siswa untuk terlibat langsung dalam kegiatan yang melibatkan siswa serta guru yang berperan sebagai pembimbing untuk menemukan konsep IPA yang salah satunya menggunakan metode Course Review Horay.

Pemilihan metode pembelajaran yang baik dapat berpengaruh signifikan terhadap hasil belajar. Guru dapat menggunakan berbagai jenis metode pembelajaran yang sesuai dengan kebutuhan siswa. Salah satu metode pembelajaran yang dapat menarik dan mendorong siswa untuk terlibat aktif dalah metode Course Review Horay. Agus Suprijono (2013: 111) mengemukakan bahwa pembelajaran Course Review Horay termasuk dalam kategori pembelajaran aktif yang menciptakan suasana belajar penuh dengan aktivitas. Aktivitas belajar pada pembelajaran Course Review Horay lebih banyak berpusat pada siswa. Aktivitas siswa dalam pembelajaran Course Review Horay memberikan suasana belajar dan interaksi yang menyenangkan, membuat siswa lebih menikmati proses pembelajaran sehingga siswa tidak merasa bosan dalam mengikuti pembelajaran IPA. Hal ini dapat meningkatkan minat siswa terhadap pembelajaran IPA.

Pembelajaran Course Review Horay merupakan suatu metode pembelajaran untuk menguji pemahaman konsep siswa menggunakan soal dan setiap kelompok membuat kartu jawaban yang diberi nomor sesuai dengan nomor soal yang dibacakan. Siswa yang mendapatkan jawaban yang benar berteriak "horee" atau yel-yel lainnya. Miftahul Huda (2015: 230) mengemukakan Metode Course Review Horay membantu siswa untuk memahami konsep dengan baik melalui diskusi kelompok. Penggunaan metode ini secara garis besar menjadikan guru berperan sebagai fasilitator dan siswa berperan sebagai subjek pembelajaran.

Hasil penelitian yang dilakukan oleh Akhmad Subchi Latif (2012) menunjukkan bahwa metode Course Review Horay memberikan pengaruh yang signifikan terhadap minat belajar dan hasil belajar siswa. Hal ini merupakan bukti empirik yang memperkuat keyakinan peneliti bahwa dengan menggunakan Metode Course Review Horay masalah rendahnya minat belajar dan hasil belajar siswa di kelas VIII F SMP N 2 Ngemplak dapat diatasi.

Alasan mengapa dipilihnya meteri mengenai sub tema organ gerak hewan karena untuk memahami berbagai organ gerak hewan. Sub tema organ gerak hewan anak masih marasa kesulitan. Berawal dari observasi dan hasil ulangan harian yang peneliti lakukan di MIN Merauke, peneliti menemukan fakta bahwa siswa kelas Va masih mengalami kesulitan dalam memahami pelajaran khususnya IPA- sub tema organ gerak hewan, hal ini disebabkan oleh beberapa faktor diantaranya adalah 1). Kurangnya kreatifitas dan ketrampilan guru dalam mengajar sehingga pembelajaran terasa membosankan dan monoton. 2). Siswa menganggap bahwa pelajaran IPA kadang sulit dipahami karena mempelajari hal yang abstrak tampa pembuktian secara konkrit dalam kehidupan nyata. 3). Dalam proses belajar mengajar selama ini hanya sebatas upaya untuk mencapai target pembelajar an dalam satu semester tanpa melihat siswa yang kurang faham terhadap meteri tertentu yang menjadikan siswa hanya terampil dalam mengerjakan soal-soal saja, sehingga pelajaran berlangsung kurang bermakna.

Dari faktor yang ada mengakibatkan prestasi belajar siswa masih dibawah KKM (Kriteria Ketuntasan Maksimum). Berangkat dari 
permasalahan-permasalahan di atas, maka peneliti mencoba menerapkan metode Course Review Horay pada mata pelajaran IPA. Metode Course Review Horay adalah suatu metode Metode Course Review Horay. Berdasarkan uraian di atas maka penulis tertarik untuk meneliti apakah dengan metode Course Review Horay prestasi belajar dapat menjamin keberhasilan dalam proses belajar mengajar. Untuk itu penulis penulis mengambil judul "Peningkatan Hasil Belajar Siswa Kelas Kelas Va MIN Merauke Pada Tema Organ Gerak Hewan Dan Manusia Sub Tema Organ Gerak Hewan Melalui Metode Course Review Horay Tahun Pelajaran 2018/2019 Semester Ganjil" Berdasarkan rumusan masalah penelitian diatas, maka tujuan penelitian ini adalah sebagai berikut: 1). Untuk mendeskripsikan penerapan metode Course Review Horay pada mata pelajaran IPA sub tema organ gerak hewan pada siswa kelas Va MIN Merauke. 2). Untuk mengetahui prestasi belajar siswa setelah diterapkannya metode Course Review Horay pada pelajaran IPA sub tema organ gerak hewan pada siswa kelas Va MIN Merauke.

\section{METODE PENELITIAN}

Penelitian ini peneliti mengambil jenis penelitian tindakan kelas. Rancangan atau desain PTK yang digunakan adalah menggunakan model PTK Kemmis \& Mc. Taggart yang ada dalam alur penelitiannya yakni meliputi langkah-langkah berikut (Aqib. Z, 2009) : a. Perencanaan (plan) b. Melaksanakan Tindakan (act) c. Melaksanakan pengamatan (observe) d. Mengadakan refleksi (reflection)

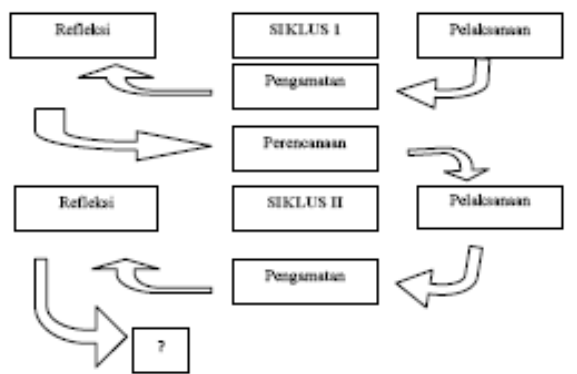

Gambar 1. Alur Penelitian Tindakan Kelas

Penelitian ini dilaksanakan di MIN Merauke.

Khususnya dilaksanakan di kelas Va dengan jumlah siswa 24 orang siswa (12 siswa laki-laki dan 12 siswa perempuan) dengan latar belakang yang berbeda.

Data yang digunakan dalam penelitian ini adalah Data yang dikumpulkan dalam penelitian ini adalah sebagai berikut:

1. Pernyataan verbal siswa dan guru yang diperoleh dari hasil wawancara sehubungan dengan proses pembelajaran dan pemahaman terhadap materi.

2. Hasil observasi yang dilakukan melalui pengamatan oleh teman sejawat dan salah satu guru IPA di sekolah tersebut terhadap aktivitas praktisi dan siswa dengan menggunakan lembar observasi yang disediakan oleh peniliti.

3. Catatan lapangan dari rangkaian kegiatan siswa dalam pembelajaran tindakan selama penelitian.

Adapun sumber data dalam penelitian ini adalah siswa kelas Va MIN Merauke yang diberikan tindakan dengan diterapkannya penggunaan metode Course Review Horay untuk meningkatkan prestasi belajar.

Teknik pengumpulan data dalam penelitian ini menggunakan empat cara yaitu Observasi, Interview / wawancara, Pre Test (Tes Awal), Post Test (Tes Akhir), Dokumentasi dan Catatan Lapangan

Data yang direduksi adalah tes awal yang berkaitan dengan materi sumber energi dan kegunaannya. Wawancara dengan Ibu Ratna selaku guru IPA kelas Va MIN Merauke dan siswa yang dipilih oleh peneliti, observasi mengenai pembelajaran IPA yang dilakukan pada saat pemberian tindakan berlangsung pada materi sumber energi dan catatan lapangan yang dilakukan oleh peneliti, teman sejawat dan guru IPA MIN Merauke mengenai hal-hal atau data-data yang mendukung peneliti dalam melakukan penelitian.

Penyajian data dapat dilakukan dalam bentuk uraian singkat, bagan, hubungan antara kategori.

Pada tahap penarikan kesimpulan ini kegiatan yang dilakukan adalah memberikan kesimpulan terhadap data-data hasil penafsiran. Kesimpulan dalam penelitian ini merupakan temuan baru yang sebelumnya belum pernah ada. Temuan tersebut dapat berupa deskripsi/gambaran suatu objek yang sebelumnya masih belum jelas, sehingga setelah diteliti menjadi jelas. Jika hasil dari kesimpulan ini kurang kuat, maka perlu adanya verifikasi. Verifikasi yaitu menguji kebenaran, kekokohan dan mencocokkan makna-makna yang muncul dari data. Pelaksanaan verifikasi merupakan suatu tujuan ulang pada pencatatan lapangan atau peninjauan kembali serta tukar pikiran dengan guru maupun teman sejawat.

Pengecekan keabsahan data yang dilakukan dalam penelitian ini difokuskan pada prestasi belajar siswa dalam materi cahaya dan sifat-sifatnya, dengan menggunakan teknik pemeriksaan tiga cara dari sepuluh cara yang dikembangkan Moleong,

Keberhasilan siswa ditentukan kriterianya, yakni berkisar antara 75-80\%. Artinya, siswa dikatakan berhasil apabila ia menguasai atau mencapai sekitar $75-80 \%$ dari tujuan atau nilai yang seharusnya dicapai.

\section{PEMBAHASAN}

Berdasarkan hasil belajar siswa sebelum tindakan (diambil dari rata-rata nilai UH1 dan UH2) dan hasil belajar siswa setelah tindakan yang dilakukan pada siklus I memperoleh persentase sebagai berikut: 

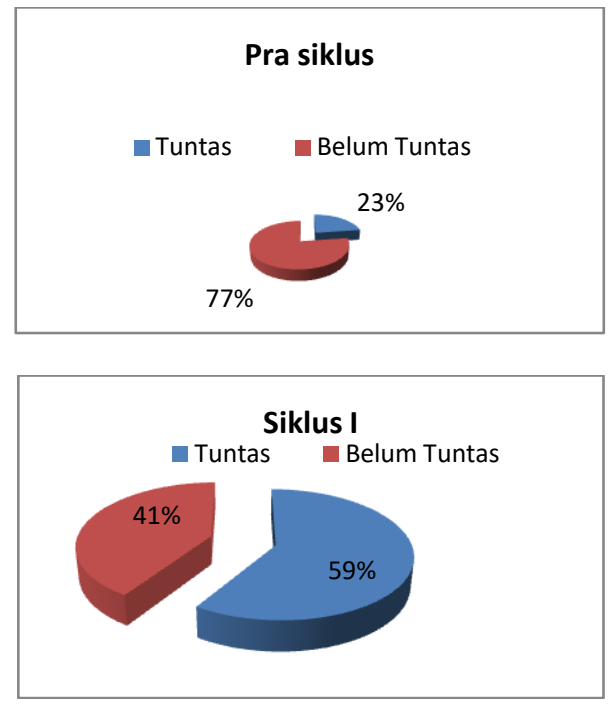

Gambar 2. Hasil Belajar Siswa Sebelum Tindakan dan Hasil Belajar Siswa Setelah Tindakan Siklus I

Gambar 3 menunjukkan bahwa di dalam kelas Va hasil belajar siswa siklus I (yang diambil dari rata-rata nilai $\mathrm{UH} 1+\mathrm{UH} 2$ ) terdapat $23 \%$ yang tuntas dan siswa tidak tuntas $77 \%$. Evaluasi pembelajaran diberikan di akhir pembelajaran, hasi belajar siswa setelah tindakan menunjukan 59\% siswa tuntas dengan $41 \%$ siswa tidak tuntas.

\subsubsection{Refleksi}

Kegiatan refleksi pada siklus I peneliti dan guru observer melakukan diskusi berdasarkan data hasil angket dan hasil belajar siswa menunjukan metode Course Review Horay dapat dilaksanakan dengan baik pada mata pelajaran IPA namun belum mampu meningkatkan minat dan hasil belajar siswa. Hasil pengamatan pada siklus I masih ditemukan beberapa kendala sebagai berikut:

1. Siswa masih pasif dalam bertanya, menjawab pertanyaan dan mengemukakan pendapat karena beberapa siswa masih asik mengobrol dengan temannya, siswa tidak memperhatikan pada saat guru menjelaskan materi.

2. Pembagian kelompok dan diskusi kelompok membutuhkan waktu yang lebih dari waktu yang telah ditentukan.

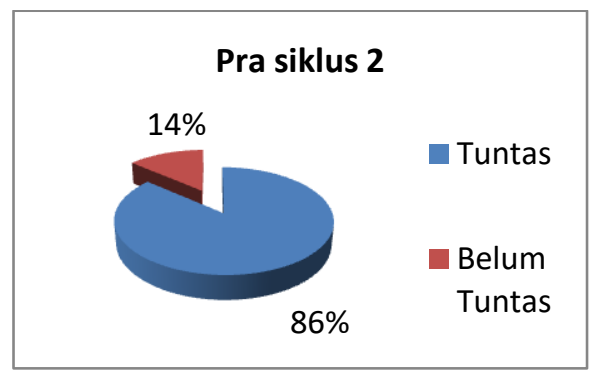

Gambar 4 menunjukkan bahwa hasil belajar siklus II sebelum tindakan (yang diambil dari rata-rata nilai $\mathrm{UH} 1+\mathrm{UH} 2$ ) terdapat $86 \%$ siswa yang tuntas dan $14 \%$ siswa tidak tuntas. Hasil belajar siswa setelah
3. Nilai hasil belajar belum mencapai indikator keberhasilan sebesar $\geq 75,00$ karena minat belajar masih rendah, sehingga siswa belum mampu untuk memahami materi yang diajarkan, dan karena kurangnya persiapan siswa dalam menghadapi soal evaluasi pembelajaran.

Berdasarkan permasalahan-permasalahan yang muncul pada siklus I, peneliti bersama guru kolabolator merencanakan langkah-langkah perbaikan sehingga minat siswa dapat lebih optimal ketika siklus II dilaksanakan.

1. Guru mengubah struktur dalam pembelajaran IPA di kelas Va untuk meningkatkan minat siswa dalam menyampaikan pendapat, bertanya, dan menjawab dengan cara menyajikan materi yang menarik siswa untuk berdiskusi dalam masingmasing kelompok. Untuk meningkatkan diskusi kelompok, guru lebih memotivasi siswa agar aktif dalam kerjasama kelompok.

2. Guru memberi peringatan secara tegas dengan memberhentikan waktu diskusi kelompok jika waktu sudah habis. Guru memberikan sanksi bagi siswa yang masih ribut dan tidak mau bekerja sama dalam diskusi kelompok.

3. Guru memberikan reward berupa buku tulis dan pena, evaluasi, dan motivasi kepada siswa agar siswa memiliki minat belajar dalam mengikuti proses pembelajaran IPA. Reward diberikan

4. kepada kelompok yang memperoleh nilai tertinggi agar kelompok lain terpacu untuk mendapatkan nilai yang baik sehingga diharapkan minat siswa dalam belajar meningkat.

5. Guru memberitahukan hasil belajar di siklus pertama untuk meningkatkan minat siswa dalam memperbaiki hasil belajarnya, sehingga siswa dapat lebih mempersiapkan diri dalam menghadapi evaluasi pembelajaran.

\subsection{Siklus II}

\subsubsection{Hasil Belajar Siswa Siklus II}

Berdasarkan hasil belajar siswa sebelum tindakan (diambil dari rata-rata nilai UH1 dan UH2) dan hasil belajar siswa setelah tindakan (diambil dari nilai evaluasi belajar) yang dilakukan pada siklus II memperoleh persentase sebagai beriku

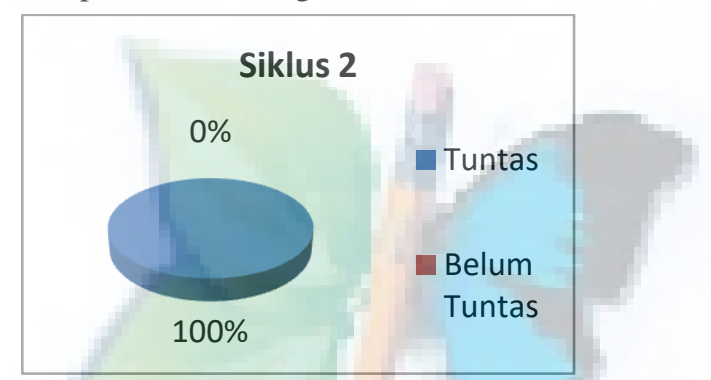

Gambar 3. Hasil Belajar Siswa Sebelum Tindakan dan Hasil Belajar Siswa Setelah Tindakan Siklus II

tindakan (diambil dari nilai evaluasi belajar) pada siklus II menunjukan $100 \%$ dan tidak ada yang tidak tuntas. 


\subsubsection{Refleksi}

Pembelajaran telah dilaksanakan dengan baik, siswa aktif dan antusias dalam mengikuti pembelajaran. Siswa bersemangat pada saat berdiskusi di dalam kelompok, dan memperhatikan ketika ada teman yang sedang mempersentasikan hasil diskusi. Penelitian ini dihentikan pada siklus II dikarenakan telah mencapai kriteria keberhasilan tindakan. Dapat dilihat dari ketercapaian nilai evaluasi belajar yang telah mencapai kriteria keberhasilan tindakan yaitu > $75 \%$.

\subsection{Pembahasan Hasil Penelitian}

Berdasarkan hasil observasi secara langsung yang dilakukan sebelum penelitian tindakan kelas. Hasil belajar siswa masih rendah. Guru dalam pembelajaran di dominasi oleh ceramah dan sedikit menggunakan metode yang cooperative learning. Oleh karena itu untuk mengatasi masalah tersebut peneliti berupaya melakukan suatu tindakan kelas yang dapat membawa kearah perbaikan dan peningkatan minat dan hasil belajar siswa melalui metode Course Review Horay.

Pembelajaran melalui metode Course Review Horay dapat meningkatkan hasil belajar siswa, seperti pada indikator pertama minat yaitu kehadiran. Peneliti menemukan adanya peningkatan siswa dalam kehadiran pembelajaran melalui ketertarikan siswa dengan cara siswa aktif memberikan pendapat maupun pertanyaan yang diberikan pada saat diskusi kelompok berlangsung. Metode Course Review Horay dapat meningkatkan ketertarikan siswa pada pembelajaran IPA dikarenakan metode Course Review Horay memberikan suasana pembelajaran yang menyenangkan dan menjadikan siswa terlibat aktif di dalam pembelajaran.

Indikator kedua yaitu perhatian. Peneliti menemukan adanya peningkatan terhadap perhatian seperti siswa selalu berkonsentrasi selama proses pembelajaran, siswa mencatat hal-hal yang penting terkait materi pembelajaran, siswa mendengarkan dan memperhatikan dengan baik pertanyaan maupun pendapat yang diberikan siswa lain. Metode Course Review Horay dapat meningkatkan perhatian siswa pada pembelajaran IPA dikarenakan metode Course Review Horay memiliki sintaks pembelajaran, dimana sintaks pembelajaran tersebut juga menekankan pada spesialisasi untuk memahami materi, mengerjakan soal, dan melakukan presentasi didepan kelas sehingga siswa diharuskan untuk memperhatikan dan berkonsentrasi selama pembelajaran untuk dapat memahami materi dan mampu menjawab pertanyaan yang akan diberikan pada metode Course Review Horay.

Indikator ketiga yaitu rasa ingin tahu. Peneliti menemukan adanya peningkatan pada rasa ingin tahu siswa dalam pembelajaran IPA. Metode Course Review Horay dapat meningkatkan rasa ingin tahu siswa karena di dalam sintaks metode Course Review Horay siswa diharuskan memahami materi yang diberikan dan berperan aktif dalam pembelajaran di kelas, dalam metode Course Review Horay siswa menanyakan materi yang belum dipahami, merespon dan menjawab pertanyaan dari guru maupun siswa yang lain sebagai bahan untuk menjawab pertanyaan yang akan diberikan dalam metode Course Review Horay.

Indikator keempat yaitu rasa senang. Peneliti menemuukan adanya peningkatan rasa senang siswa terhadap pembelajaran IPA. Metode Course Review Horay memberikan peningkatan terhadap rasa senang yang dimiliki siswa dalam pembelajaran. Siswa bersemangat dalam mengikuti pembelajaran menjadikan siswa ikut berperan aktif dalam pembelajaran, siswa selalu mengerjakan tugas tepat waktu dan mampu memahami materi dengan menjawab pertanyaan metode Course Review Horay dengan baik dibuktikan dengan nilai hasil belajar yang sudah memenuhi criteria keberhasilan telah mengalami peningkatan pada siklus I ke siklus II.

Berdasarkan hasil penelitian dan uraian diatas maka diketahui bahwa penggunaan metode Course Review Horay memberikan dampak terhadap peningkatkan hasil belajar siswa kelas Va MIN Merauke dalam pembelajaran IPA. Hal ini terlihat dari nilai rata-rata yang telah dibandingkan dari siklus I dan siklus II.

\section{KESIMPULAN}

Berdasarkan hasil dari penelitian tindakan yang telah dilakukan diperoleh kesimpulan sebagai adalah peningkatan hasil belajar siswa berdasarkan hasil angket minat belajar dari siklus I ke siklus II masuk dalam kriteria tinggi. Peningkatan hasil belajar dari siklus I ke siklus II berhasil mencapai kriteria ketuntasan minimal. Peningkatan hasil minat dan hasil belajar telah memenuhi kriteria keberhasilan.

\section{DAFTAR PUSTAKA}

Ahmadi.A dan Supriyanto.W, (2008). Psikologi Belajar, Jakarta: PT Rieneka Cipta

Aqib. Z, (2009), Penelitian Tindakan Kelas, Bandung: Yrama Widya

Arifin M dan Aminuddin Rasyad, A (1997), DasarDasar Pendidikan, Jakarta: Dirjen PembinaanAgama Islam.

Arifin. Z, (2011). Evaluasi Pembelajaran, Bandung: PT Remaja Rosdakarya

Arikunto,S. (2002), Prosedur Penelitian Suatu Pendekatan Praktek. Yogyakarta: Rineka Cipta

Arikunto,S. dkk, (2008). Penelitian Tindakan kelas, Jakarta Bumi Aksara

Asmani. JM. (2009), Tips Menjadi Guru Ispiratif, Kreatif dan Inovatif, Jogjakarta: Diva Press.

Asrori. M, (2007). Penelitian Tindakan Kelas, Bandung, Bumi Rencaekek Kencana

Aswanin dan Usman.B.(2002), Media Pembelajaran, Jakarta: PT Intermasa, 
Daryanto, (2011). Penelitian Tindakan Kelas dan Penelitian Tindakan Sekolah, Yogyakarta, Gava Media

Departemen Agama RI (2007). Kumpulan UndangUndang dan Peraturan Pemerintah RI Tentang Pendidikan, Jakarta: Direktorat Jendral Pendidikan

Djamarah SB dan Zain. A, (2010). Strategi Belajar Mengajar, Jakarta PT. Rineka Cipta

Djamarah.SB. (2012), Prestasi Belajar dan Kompetensi Guru, Surabaya: Usaha Nasional

Hamalik O (2001). Proses Belajar Mengajar, Jakarta: Bumi Aksara

Haryono, (2002). Pembelajaran IPA yang Menarik dan Mengasyikan dalam Teori dan Aplikasi PAIKEM, Yogyakarta: Kepel Press

Hasan, I (2002). Pokok-pokok Materi Metodologi Penelitian dan Aplikasinya, Jakarta: Ghalia Indonesia.

Hasibuan dan Moedjiono, (2010). Proses Belajar Mengajar, Bandung: PT remaja Rosdakarya

Margono. S, (2000). Metodologi Penelitian Pendidikan. Jakarta: Rineka Cipta

Moleong. LJ, (2010). Metodologi Penelitian kualitatif, Bandung: PT Remaja Rosdakarya,

Mu'awanah. E, (2000), Evaluasi Pendidikan, Tulungagung: Pusat Penerbitan dan Publikasi STAIN Tulungagung,

Mufarokah A, (2009). Strategi Belajar Mengajar, Yogyakarta: Teras

Mulyasa E, (2008). Menjadi Guru Profesional, Bandung: PT Remaja rosdakarya.
Mulyasa, (2005), Kurikulum Berbasis Kompetensi, Bandung: PT. Remaja Rosdakarya

Mulyasa, (2005). Kurikulum Berbasis Kompetensi, Bandung: PT Remaja Rosdakarya

Mulyasa, (2011). Kurikulum Tingkat Satuan Pendidikan, Bandung: PT Remeja Rosdakarya,

Purwanto N, (2008). Prinsip-prinsip dan Teknik Evaluasi Pengajaran, Bandung: Rosdakarya

Purwanto. N, (2008). Prinsip-Prinsip dan Teknik Evaluasi Pengajaran, Bandung: PT Remaja Rosdakarya.

Sunaryo, et all, (2005). Modul Pembelajaran Eksklusif Gender, Jakarta: Menera Revindo

Suwarna, et all. (2006) Pengajaran Mikro, Yogyakarta: Tiara Wacana

Suwarna, et all. (2006). Pengajaran Mikro, Yogyakarta: Tiara Wacana.

Tanzeh. A, (2011). Metedologi Penelitian Praktis, Yogyakarta: Teras

Tirtarahardja U, (2005). Pengantar Pendidikan, Jakarta: Rineka Cipta.

Trianto, (2007) Wawasan Ilmu Alamiah Dasar Perspektif Islam dan Barat, Jakarta:Prestasi Pustaka,

Trianto, (2007). Model Pembelajaran Terpadu dalam Teori dan Praktek, Jakarta: Prestasi Pustaka,

Wiriaatmadja. R (2005), Metodologi Penelitian Tindakan Kelas Untuk Meningkatkan Kinerja Guru dan Dosen, Bandung: PT Remaja Rosdakarya

Yamin, (2007). Evaluasi Hasil Belajar, Jakarta: Departemen Pendidikan dan Kebudayaan 